\title{
ОСНОВНІ ПУБЛІКАЦІї
}

УДК:614.3:632.95:63-027.3:339.564

DOI: 10.15407/zht2018.64.005

БАРАНОВ Ю.С, ДЕМЧЕНКО В.Ф. ${ }^{1}$, ЗЕМЦОВА О.В

\section{МЕТОДИ ВИЗНАЧЕННЯ МУЛЬТИЗАЛИШКОВИХ КІЛЬКОСТЕЙ ПЕСТИЦИДІВ В УКРАЇНІ}

\begin{abstract}
Обгрунтовано необхідність розробки методик визначення мультизалишкових кількостей (multiresidues methods, MRM) пестицидів в об'єктах довкілля та харчових продуктах. Виконано аналіз досягнень вітчизняної школи аналітичної хімї пестицидів у створенні MRM від аналітичних схем систематичного визначення залишків пестицидів при їх сумісній присутності в одній пробі до мультизалишкових методик вимірювання масової концентрації пестицидів в продукції агропромислового комплексу, об'єктах довкілля із застосуванням твердофазної екстракиії, газорідинної хроматографії/масспектрометрії, високоефективної рідинної хроматографії/тандемної мас-спектрометрії. Наведено порівняльний аналіз стандартних гармонізованих в Украӥні MRM визначення пестицидів. Описано переваги сучасного стандартного методу EN 15662-2008, розглянуто варіанти модифікаиіï методу QuEChERS для випробувань високоліпідних матриць та визначення полярних аналітів не лише пестицидів, але й мікотоксинів, поліароматичних вуглеводнів, антибіотиків, поліхлорованих біфенілів та інших груп ксенобіотиків в об'єктах довкілля та продукиії агропромислового комплексу, представлено внесок вітчизняних аналітиків у вдосконалення методології QuEChERS.
\end{abstract}

Ключові слова: твердофазна екстракиія, газорідинна хроматографія/масспектрометрія, високоефективна рідинна хроматографія/тандемна мас-спектрометрія, методики визначення мультизалишкових кількостей пестицидів (multiresidues methods, MRM), методологія QuEChERS, метод EN 15662-2008, високоліпідні матриці, полярні аналіти, мікотоксини, поліароматичні вуглеводні, антибіотики.

Обоснована необходимость разработки методик определения мультиостаточных количеств (multiresidues methods, MRM) пестицидов в объектах окружающей среды $и$ продуктах питания. Проведен анализ достижений отечественной школь аналитической химии пестицидов в создании MRM от аналитических схем систематического определения остатков пестицидов при совместном присутствии в одной пробе до мультиостаточных методик измерения массовой концентрации комплексов пестицидов в продукции агропромышленного комплекса, объектах окружающей среды с применением твердофазной экстракиии, газожидкостной хроматографии/масс-спектрометрии, высокоэффективной жидкостной хроматографии/тандемной масс-спектрометрии. Приведен сравнительный анализ стандартных гармонизированных в Украине MRM определения пестицидов. Доказаны преимущества современного стандартного метода EN 15662-2008, рассмотрень варианты модификации метода QuEChERS для анализа матрии с высоким содержанием липидов и определения полярных аналитов не только пестиџидов, но и микотоксинов, полиароматических углеводородов, полихлорированных бифенилов и других групп ксенобиотиков в объектах окружающей среды и продукции агропромышленного комплекса, представлен вклад отечественных аналитиков в совершенствование методологии QuEChERS.

Ключевые слова: твердофазная экстракичи, газожидкостная хроматография/массспектрометрия, высокоэффективная жидкостная хроматография/тандемная массспектрометрия, методики определения мультиостаточных количеств 
(multiresidues methods, MRM) пестицидов, методология QuEChERS, метод EN 15662-2008, высоколипидные матрииы, полярные аналиты, микотоксины, полиароматические углеводороды, антибиотики.

The necessity of development of multiresidues methods (MRM) of pesticides determination in the objects of environment and foodstuffs is substantiated. An analysis of the achievements of the national school of pesticides analytical chemistry in the creation of MRM has been carried out from the analytical schemes of systematic determination of pesticide residues co-presence in one sample to multiresidues methods for measuring the mass concentration of pesticides in agroindustrial products, environmental objects using solid extraction, gas-liquid chromatography/mass spectrometry, high performance liquid chromatography/tandem mass spectrometry. The standartized harmonized MRM of pesticide determination are presented, variants of modification of QuEChERS method for testing of highly lipid matrices and determination of polar analytes, not only pesticides but also mycotoxins, polyaromatic hydrocarbons, antibiotics, polychlorinated biphenyls and other groups of xenobiotics in the objects of environment and products of agrarianindustrial complex are considered. The advantages of the modern standard method EN 15662-2008 are proved, the contribution of ukrainian analysts in improving the QuEChERS methodology is presented.

Key words: solid phase extraction, gas-liquid chromatography/mass spectrometry, high performance liquid chromatography/tandem mass spectrometry, multiresidues methods (MRM) of pesticides determination, QuEChERS methodology, method EN 15662-2008, lipid matrices, polar analytes, mycotoxins, polyaromatic hydrocarbons, antibiotics.

Інтенсифікація сільського господарства, що набула широкого запровадження (поширена в 60 - 70-х роках минулого століття), була викликана необхідністю підвищення обсягів виробництва продукції агропромислового комплексу (АПК) в умовах дефіциту робочої сили і базувалася на активному застосуванні хімічних засобів захисту рослин та підвищенні рівня механізації. Це в свою чергу призвело до стрімкого розвитку хімії пестицидів - на зміну стійким хлорорганічним пестицидам (ХОП) прийшли спочатку фосфорорганічні сполуки (ФОС), потім синтетичні піретроїди, а наприкінці сторіччя неонікотиноїди. 3'явилися нові хімічні групи фунгіцидів (карбамати, триазоли, стробілурини) та гербіцидів (фенілсечовини, сим-триазини, ацетаніліди, пізніше сульфонілсечовини).

Зростання пестицидного навантаження на об'єкти довкілля підвищило ймовірність забруднення харчових продуктів та викликало нові ризики для здоров'я людини.

На той час аналітичний контроль залишків пестицидів у продукції АПК та об’єктах навколишнього середовища було побудовано на використанні так званих single-методик (призначених для визначення залишків одного пестициду в одній матриці), що розроблялись як невід’ємна складова забезпечення реєстрації пестицидів та постреєстраційного контролю. 3 часом стало зрозуміло, що single-методики були не в змозі забезпечити надійний контроль залишків пестицидів в умовах інтенсифікації сільського господарства.

Враховуючи нові виклики, засновником вітчизняної школи аналітичної хімії пестицидів професором Клисенко М.А. з учнями розпочато розробку методів визначення мультизалишкових кількостей пестицидів (multiresidues methods, MRM) в умовах обмеженої бази вимірювального обладнання. Так з'явився новий напрямок в аналітичній хімії пестицидів, сьогодні відомий як «систематичний хід визначення залишків пестицидів при сумісній присутності в одній пробі». Принцип методу було засновано на підборі універсального способу вилучення комплексу пестицидів з матриці, розподілу пестицидів 3 екстрактів на хімічні групи, використовуючи відмінності у фізико-хімічних властивостях молекул (рКа, $\mathrm{pH}$ водних розчинів, $\log _{\mathrm{o} / \mathrm{w}}$ тощо) та їх визначенні методами тонкошарової та газорідинної хроматографії (ГРХ) з електроннозахватним детектором (ЕЗД), термоіонним детектором хромато-ферментним методом. Основні принципи роботи 3 аналізу багатокомпонентних сумішей пестицидів було підсумовано Клисенко М.А. зі співавторами [1]. 
Систематичний хід визначення залишків пестицидів за їх сумісній наявності в одній пробі було успішно реалізовано у розробках лабораторій аналітичної хімії пестицидів Всесоюзного науково-дослідного інституту гігієни та токсикології пестицидів, полімерів $\mathrm{i}$ пластичних мас (ВНДІГІНТОКС) (нині ДП «Науковий центр превентивної токсикології, харчової та хімічної безпеки імені академіка Л.І. Медведя MO3 України») та Київського науково-дослідного інституту гігієни праці та профзахворювань (КНДІ ГПіПЗ) (нині ДУ «Інститут медицини праці імені Ю.І. Кундієва НАМН України» $[2,3,4,5,6]$, Українського науково-дослідного інституту захисту рослин (УНДІЗР) (нині «Інститут захисту рослин НААН України» [7, 8], Всесоюзного науково-дослідного інституту ефіроолійних культур (ВНДІЕОК, м. Симферопіль) [9].

Створення системи мультизалишкового визначення пестицидів у продукції АПК слугувало поштовхом для появи окремого напрямку аналітичного контролю різноманітних пестицидів, застосовуваних в тій чи іншій агротехнології вирощування сільськогосподарських культур. Так, було розроблено методики систематичного визначення залишків пестицидів, що застосовувались в інтенсивних технологіях вирощування ефіроолійних культур (ВНДІЕОК), плодово-овочевих культур (ВНДІГІНТОКС), зернових та цукрового буряку (УНДІЗР).

Запропоновано мультизалишкові методики для контролю забруднення об'єктів довкілля - грунтів, води та рослин (ВНДІГІНТОКС та ВНДІЕОК), а також харчових раціонів (ВНДІГІНТОКС). Для виявлення експозиції людини пестицидами, діагностики професійних та екозалежних отруєнь та профзахворювань розроблено методичні вказівки по систематичному ходу аналізу біологічних середовищ (крові, сечі тощо) на вміст пестицидів різної хімічної природи (КНДІГПіПЗ та ВНДІГІНТОКС).

В той же час міжнародна аналітична спільнота сконцентрувалась на розробці MRM визначення залишків пестицидів, які грунтувались на досягненнях аналітичного приладобудування: комп'ютерного програмного забезпечення, капілярних хроматографічних колонок, твердофазної екстракції (ТФЕ), оригінальних систем інжекції проби, нових детекторів у ГРХ та високоефективній рідинній хроматографії (ВЕРХ), в першу чергу мас-спектрометричних (MC) детекторів, автоматизованих систем екстракції та очистки екстрактів, нових селективних сорбентів та реактивів. Завдяки реалізації більшості досягнень значно спростились вимоги до чистоти аліквот, що інжектують у хроматограф, у рази підвищилась селективність та зменшилася межа кількісного визначення (МКВ) аналітичних методик, автоматизувались процеси пробопідготовки, інжектування, керування роботою приладів, значно пришвидшився процес отримання протоколів вимірювання.

3'явилась велика кількість MRM визначення залишків пестицидів у різних матрицях об'єктів довкілля та харчових продуктів. Підсумком багаторічної роботи аналітиків 3 розроблення MRM визначення залишків пестицидів стали відповідні аналітичні стандартні методики $[10,11,12,13,14,15,16]$, які було гармонізовано в Україні.

На рис. 1 наведено детальну блок-схему стандартної аналітичної процедури визначення мультизалишків пестицидів у зернових (основна складова агроекспорту України) за стандартним методом згідно з ДСТУ ЕN 12393-1,2,3:2003 [10].

Незважаючи на очевидні переваги (висока селективність, одночасне визначання 56 аналітів, достатня МКВ) і задіяні сучасні аналітичні методи та прилади (капілярна хроматографія, ТФЕ, селективні детектори), методика є досить трудомісткою, клопіткою, витратною та довготривалою (18-20 годин).

В Україні з об'єктивних обставин наприкінці XX-го - початку XXI-го сторіччя MRM визначення залишків ксенобіотиків взагалі не розроблялись, аналітики користувалися стандартними гармонізованими методиками, що згадані вище. Виняток становить атестована MRM визначення залишків пестицидів у грунті [17], яку було розроблено в Українській лабораторії якості та безпеки продукції АПК Національного університету біоресурсів та природокористування МОН України (УЛЯБП АПК НУБіП України) у 2006 році та використано з метою моніторингу забруднення грунтів $[18,19,20]$. 
20-50 г ( \pm 0,01 г) зразка з визначеним вмістом вологи поміщають у конічну колбу на $500 \mathbf{c m}^{3}$, додають $350 \mathbf{c m}^{3}$ суміші для екстрагування (ацетонітрил/вода), струшують 30 хв на швидкості 200 об/хв

фільтрують крізь паперовий фільтр (червона стрічка)

у конічну колбу на 500 см$^{3}$, переносять фільтрат у ділильну воронку на $1 \mathbf{c m}^{3}$

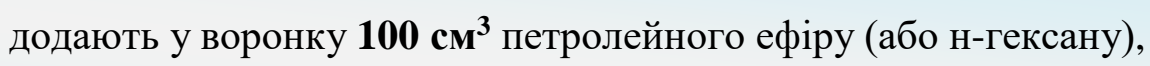
інтенсивно струшують протягом 2 хв,

додають $10 \mathbf{c m}^{3}$ насиченого розчину $\mathrm{NaC} 1$ та $600 \mathbf{c m}^{3}$ води

інтенсивно струшують протягом 15 с, дають час шарам розділитися, відкидають водний шар, промивають органічний шар 2 порціями води по $100 \mathbf{c m}^{3}$, промивні води відкидають

органічний шар переливають у конічну колбу на 100 см³ $^{3}$, додають 15 г $\mathrm{Na}_{2} \mathrm{SO}_{4}$, інтенсивно перемішують та фільтрують

концентрують фільтрат на водяній бані за температури $35-40^{\circ} \mathrm{C}$ та вакуумі 20 мм рт. ст. до 5-10 см$^{3}$

заповнюють хроматографічну колонку 3 см активованого флоризилу та 1 см $\mathrm{Na}_{2} \mathrm{SO}_{4}$, промивають колонку 10 см$^{3}$ петролейного ефіру (або н-гексану), відкидають промивну рідину

переносять концентрат на підготовлену колонку

(промивають колбу 2 порціями по $5 \mathbf{c m}^{3}$ петролейного ефіру, переносять на колонку), елююють 60 см$^{3}$ сумішшю (діетиловий етер/петролейний ефір 15/85 об./об.)

об’єднаний елюат концентрують до 1 краплі, розчинюють в 1 см $^{3}$ н-гексану, переносять у віалу для хроматографування за методом газорідинної хроматографії з електроннозахватним детектором

Puc.1. Блок-схема підготовки проб для проведення дослідження зернових на залишки пестицидів за методом згідно з ДСТУ ЕN 12393-1,2,3:2003 
Методика дозволяла визначати залишки 40 пестицидів різних хімічних груп (ХОП, ФОС, триазини, динітроаніліни, ацетаніліди) в грунтах різних типів на рівні, що відповідає вимогам контролю за додержанням відповідних санітарно-гігієнічних нормативів.

На початку XXI сторіччя стало зрозуміло, що метод згідно з ДСТУ EN 123931,2,3:2003 [10] вже не в змозі забезпечити зростаючий попит на швидкий та якісний контроль експортно орієнованої продукції АПК.

Запропонований у 2003 році метод підготовки проб QuEChERS (Quick, Easy, Cheap, Effective, Rugged and Simple) [21] став значним кроком у розробці MRM визначення залишків пестицидів. Пізніше, як показала аналітична практика, методологія підготовки проб QuEChERS, яка заснована на багатоцільовій екстракції та дисперсійній ТФЕ у поєднанні 3 сучасними аналітичними методами (ГРХ/МС та високоефективна рідинна хроматографія/тандемна мас-спектрометрія (BEPX/MC/MC); капілярний електрофорез) стала основним інструментом визначення мультизалишків ксенобіотиків у різних матрицях.

Дуже скоро метод QuEChERS пройшов міжнародну валідацію в багатьох лабораторіях світу та став міжнародним стандартом [22], УЛЯБП АПК НУБіП України у 2007 р. теж приймала участь у цій валідації.

Переваги методу QuEChERS заявлені в абревіатурі назви (швидкий, ефективний, дешевий, легкий, надійний, безпечний). Дійсно, аналіз блок-схеми проведення дослідження зерна на залишки пестицидів за методом згідно з EN 15662, QuEChERS, рис. 2, свідчить про задекларовані якості методу, при цьому витрати часу на визначення комплексу пестицидів (не менше 100 діючих речовин) в одній пробі зернової продукції не перевищують 30 хвилин.

10 г гомогенізованого зразку поміщають в 50 см$^{3}$ поліпропіленову (ПП) центрифужну пробірку, додають 9 см ${ }^{3}$ води та 10 см$^{3}$ ацетонітрилу,

струшують на шейкері протягом 1 хв

додають 4 г $\mathrm{MgSO}_{4}, 1$ г $\mathrm{NaCl}$, струшують на шейкері 1 хв, центрифугують протягом 7-10 хв за 7000 об/хв

відбирають аліквоту (5 $\left.\mathbf{c m}^{3}\right)$ екстракту, переносять кількісно до картриджа для

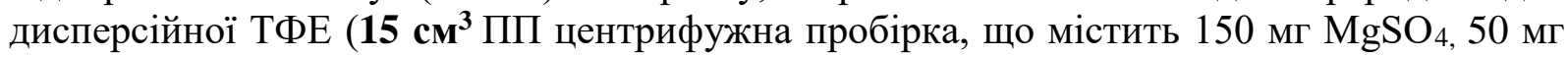
PSA*, 20 мг сорбента C18 **), струшують 1 хв, центрифугують 7-10 хв за 6000 об/хв

відбирають аліквоту (2 $\left.\mathbf{c m}^{3}\right)$, поміщають у віалу для хроматографування та інжектують відповідний об'єм у хроматограф (капілярна ГРХ/MC, ВЕРХ/MC/MC)

Примітка: * PSA (primary secondary amine) - первинно вторинний амін ** сорбент C18 - ODS (octadecyl sorbent) - октадецил сорбент

Puc.2. Блок-схема проведення дослідження зерна на залишки пестицидів за методом EN 15662, QuEChERS

Дуже швидко провідні фірми, що виробляють аналітичне устаткування, витратні матеріали та реактиви, усвідомлюючи зростаючий попит на витратні матеріали методу QuEChERS, випустили серії картриджів (готових сумішей для екстракції та дисперсійної TФЕ), використання яких ще більше спростило та пришвидшило аналітичну процедуру. На сьогоднішній день, крім стандартного методу EN 15662, існує близько 900 методик, в яких у різних варіантах та пропорціях екстрагентів та сорбентів застосована методологія QuEChERS.

Безумовно, метод пробопідготовки QuEChERS не $є$ універсальним, але сама методологія QuEChERS дуже приваблива для хіміків-аналітиків за рахунок очевидних переваг, у першу чергу дисперсійної ТФЕ. Обмеження методу викрились ще на першому етапі його створення, тому автори рекомендували застосовувати QuEChERS у першу чергу 
для визначення неполярних або малополярних гідрофобних молекул пестицидів у матрицях 3 вмістом ліпідів не більше 4\%. Це обмеження задекларовано в аналітичному стандарті EN 15662.

Аналізуючи дані таблиці 1, можна прогнозувати, що для визначення неполярних гідрофобних молекул пестицидів (ХОП, ФОС, динітроаніліни та інші) може бути застосовано варіант QuEChERS 3 дисперсійною TФЕ: PSA, GCB (graphitized carbon black активоване вугілля), ODS (C18). Проблеми в отриманні нормованих валідаційних характеристик (коєфіціент повернення Rec (recovery) - 70-120\%, відносне середнє квадратичне відхилення RSD (relative standard deviations) - 20\%) виникають при визначенні навіть малополярних пестицидів (імідазолінонів, сульфонілсечовин), тому в стандарті EN 15662 пропонують взагалі не використовувати дисперсійну ТФЕ для визначення пестицидів цих хімічних груп. Також без очистки, але 3 використанням для екстракції підкисленого мурашиною кислотою метанолу, запропоновано у відомій методиці EURL (European Union Reference Laboratories) визначення високополярних пестицидів (фосетил, гідразид малеїнова кислота, етефон, гліфосат, глюфосинат, фосфонова кислота, мепікват, хлормекват) за методом QuEChERS [23], рис. 3.

Таблиця 1

Фізико-хімічні властивості молекул пестицидів, щцо впливають на екстракцію та вибір варіанта дисперсійної ТФЕ при застосуванні пробопідготовки

\begin{tabular}{|c|c|c|c|c|}
\hline $\begin{array}{c}\text { Пестицио, } \\
\text { діюча речовина }\end{array}$ & $\begin{array}{c}\log P_{o / w} \\
(p H=7 \\
\left.20^{\circ} \mathrm{C}\right)\end{array}$ & $\begin{array}{c}p K a \\
\left(25^{\circ} C\right)\end{array}$ & $\begin{array}{c}\text { Розчинність } \\
\text { у воді }\left(20^{\circ} \mathrm{C}\right), \\
{\text { мг } / \partial \boldsymbol{M}^{3}}\end{array}$ & $\begin{array}{c}\text { Картриджс для } \\
\text { дисперсійної } \\
\text { ТФЕ }\end{array}$ \\
\hline тебуконазол & 3,7 & 5,0 & 36,0 & PSA, GCB, C18 \\
\hline пендиметалін & 5,4 & 2,8 & 0,33 & PSA, GCB, C18 \\
\hline піриміфос-метил & 3,9 & 4,3 & 11,0 & PSA, GCB, C18 \\
\hline$\lambda$-ГХЦГ & 3,50 & - & 8,2 & PSA, GCB, C18 \\
\hline імазапір & 0,11 & 11,0 & 9740 & C18 \\
\hline хлорсульфурон & $-0,99$ & 3,4 & 12500 & C18 \\
\hline 2,4-Д & $-0,82$ & 3,4 & 24300 & C18 \\
\hline гліфосат & $-3,2$ & 2,34 & 10500 & C18 \\
\hline глюфосинат амонію & $-4,01$ & 9,15 & 500000 & C18 \\
\hline фосетил-алюмінію & $-2,1$ & 4,7 & 111300 & C18 \\
\hline дикват & $-4,6$ & - & 718000 & C18 \\
\hline хлормекват-хлорид & $-3,47$ & - & 886000 & C18 \\
\hline пропамокарб & 0,84 & 9,5 & 900000 & C18 \\
\hline пропамокарб-гідрохлорид & $-1,3$ & 9,6 & 1005000 & C18 \\
\hline
\end{tabular}

Ідентифікацію та кількісне визначення пестицидів у цьому випадку виконують за допомогою $\mathrm{BEPX/MC/MC} \mathrm{не} \mathrm{тільки} \mathrm{за} \mathrm{рахунок} \mathrm{того,} \mathrm{що} \mathrm{молекули} \mathrm{пестидів} \mathrm{нелеткі,}$ напівлеткі та високополярні, але й тому, що використання методу з високою роздільною здатністю (BEPX/MC/MC) зменшує негативний вплив матриці.

Модифіковану методику визначення «кислих» пестицидів (2,4-Д, 2,4,5-Т, бентазон, бромоксиніл, клопіралід, далапон, дикамба, феноксапроп, флуазифоп, флуроксипір, галаксифоп, імізамокс, імазапір, (4-хлор-2-метилфенокси)оцтова кислота (MCРА) та інші) 3 використанням спрощеної методології QuEChERS було використано у EURL [24], рис. 4. При цьому цитратний буфер та очистка дисперсійною ТФЕ не використовувались, а методом ідентифікації та кількісного визначення була ВЕРХ/MC/MC. 


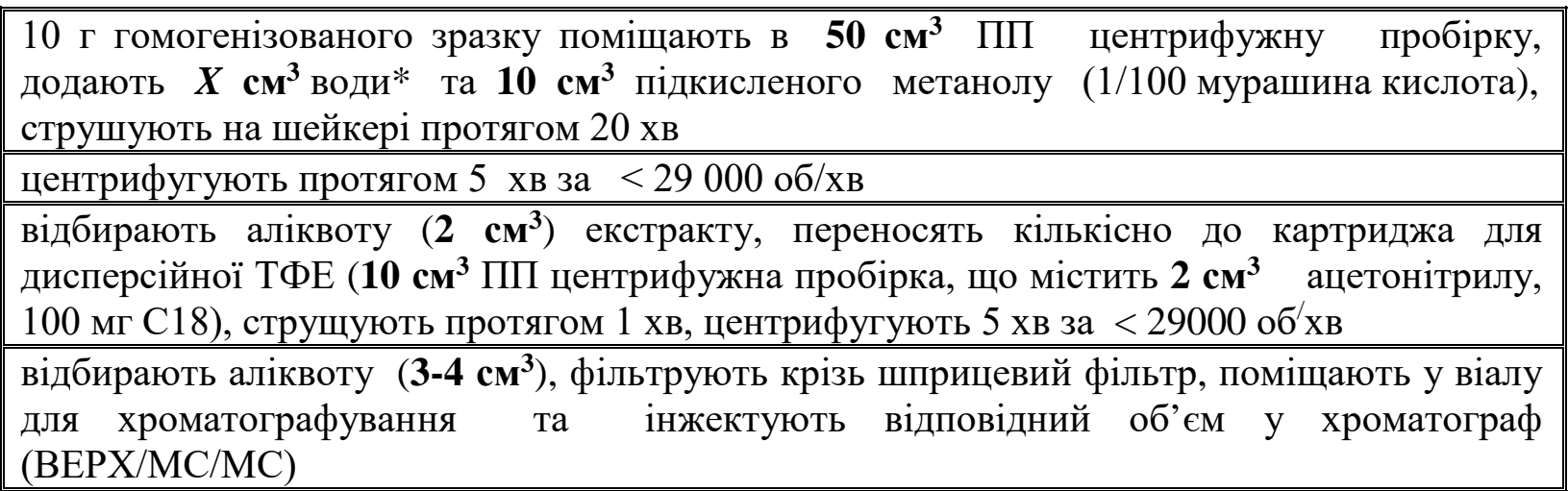

Примітка: * кількість води, яку додають, залежить від іiі вмісту у матриці

Puc.3. Блок-схема проведення дослідження молока та яєць на залишки полярних пестицидів за методом QuPPe-AO-Method, (модифікований QuEChERS)

5 г наважки подрібненого зерна

поміщають у ПП центрифужну пробірку на $50 \mathbf{c m}^{3}$, додають 10 см $^{3}$ води

додають 0,3 см$^{3} 5$ н розчину $\mathrm{NaOH}$, інтенсивно струшують протягом 1 хв, залишають суміш на 30 хв, періодично струшуючи (кожні 10 хв)

додають 0,3 см $^{3} 5$ н розчину $\mathrm{H}_{2} \mathrm{SO}_{4}$ та 10 см$^{3}$ ацетонітрилу, інтенсивно струшують протягом 1 хв

додають суміш солей: 4 г $\mathrm{MgSO}_{4}$ безводного, 1 г $\mathrm{NaCl}$, інтенсивно струшують протягом 1 хв

центрифугують протягом 5 хв за 3000 об/хв,

$7 \mathbf{c m}^{3}$ органічної фази

переносять у ПП центрифужну пробірку,

поміщають на 2 год. (або на ніч) у холодильник

$1 \mathbf{c m}^{3}$ екстракту переносять у віалу для хроматографування

Puc.4. Блок-схема проведення досліджень зернових на залишки «кислих» пестицидів за методом QuEChERS 
Найбільш суттєвим обмеженням методології QuEChERS є недостатній захист аналіту від негативного впливу матриці, особливо тієї, що має великий вміст ліпідів. Класичні варіанти методу не в змозі забезпечити чітку ідентифікацію пестицидів при їх визначенні у харчових продуктах з вмістом ліпідів більше ніж 6,0\%, навіть із застосуванням методик ГРХ/МС та ВЕРХ/МС/МС. Використання для дисперсійної ТФЕ сорбентів на основі оксиду цирконію забезпечило часткове вирішення проблеми [25]. Спеціалістами фірми Agilent Technologies було запропоновано принципово новий підхід для визначення залишків ксенобіотиків у матрицях із високим вмістом ліпідів - так зване друге покоління QuEChERS [26, 27]. Запропонований метод базується на вилученні пестицидів та антибіотиків з високоліпідних матриць підкисленим ацетонітрилом та очищенні екстрактів у два етапи із застосуванням методики розширеного вилучення ліпідів матриці - Enhanced Matrix Removal-Lipid (метод EMR-Lipid). При цьому автори використовували як ГРХ/MC [26] для визначення пестицидів, так і BEPX/MC/MC [27] для визначення ветеринарних препаратів.

В УЛЯБП АПК НУБіП України метод на основі методології QuEChERS, стандартний метод EN 15662, було використано для визначення мультизалишків пестицидів у зерновій продукції [28], модифіковано разом 3 ДУ ІМП НАМН України для визначення мультизалишків пестицидів у грунті [19], продукції сільськогосподарських культур, а також розроблено оригінальну мультизалишкову методику визначення пестицидів в оліях та олієвмісній сировині, продукції бджільництва.

Таким чином, на сьогоднішній день метод QuEChERS є основним міжнародно визнаним методом визначення мультизалишків не тільки пестицидів, але й мікотоксинів, поліароматичних вуглеводнів, антибіотиків, поліхлорованих біфенілів та інших груп ксенобіотиків в об’єктах довкілля та продукції АПК.

\section{ЛITEPATУРA}

1. М.А. Клисенко, Л.Г. Александрова, В.Ф. Демченко, Т.Л. Макарчук. Аналітична хімія залишкових кількостей пестицидів. Навч. Посібник. Київ: ЕКОГІНТОКС, 1999, 238 с.

2. Письменная М.B. Методические указания по определению в одной пробе фосфорорганических и хлорорганических пестицидов, применяемых на томатах, хроматографическими методами. Meтоды определения микроколичеств пестициидв 8 продуктах питания, кормах и внешней среде. Справочник. М.: Агропромиздат, 1992. Т.2. C.74-80.

3. Письменная M.В. Методические указания по определению синтетических пиретроидов, фосфорорганических пестицидов, севина и беномила при совместном присутствии в плодово-овощных культурах. Meтоды определения микроколичеств пестищидов в продуктах питания, кормах и внешней среде. Справочник. М.: Агропромиздат, 1992. T.2. C.80-83.

4. Кофман И.Ш. Методические указания по систематическому газохроматографическому определению микроколичеств гербицидов различной химической природы при совместном присутствии в пробах воды, почвы и растениях. Meтоды определения микроколичеств пестицидов в продуктах питания, кормах и внешней среде. Справочник. М.: Агропромиздат, 1992. Т.2. С.83-89.

5. Александрова Л.Г. Методические указания по систематическому ходу анализа биологических сред на содержание пестицидов различной химической природы. Meтоды определения микроколичеств пестищидов в продуктах питания, кормах и внешней среде. Справочник. М.: Агропромиздат, 1992. Т.2. С.89-94.

6. Гиренко Д.Б. Унифицированный метод определения остатков пестицидов при их совместном присутствии в пищевых рационах. Методы определения микроколичеств пестицидов в продуктах питания, кормах и внешней среде. Справочник. М.: Агропромиздат, 1992. T.2. C.94-97. 
7. Бублик Л.И. Методические указания по определению смеси карбофурана с беномилом и ТМТД (препарат КОМБИ) в растениях сахарной свеклы методом тонкослойной хроматографии. Методы определения микроколичеств пестищидов в продуктах питания, кормах и внешней среде. Справочник. М.: Агропромиздат, 1992. Т.2. С.97-99.

8. Кавецкий В.H. Методические указания по определению смеси метафоса, байлетона и тилта в растениях пшеницы методом тонкослойной хроматографии. Meтоды определения микроколичеств пестицидов в продуктах питания, кормах и внешней среде. Справочник. М.: Агропромиздат, 1992. Т.2. С.100-101.

9. Баранов Ю.С. Методические указания по совместному определению прометрина, тербацида и трефлана в одной пробе почвы, эфирного масла и эфиромасличного сырья мяты перечной методом газожидкостной хроматографии. Mетоды определения микроколичеств пестицицов в продуктах питания, кормах и внешней среде. Справочник. М.: Агропромиздат, 1992. T.2. C.101-105.

10. ДСТУ EN 12393-1,2,3:2003 Продукти харчові нежирові. Визначення вмісту залишків пестицидів газохроматографічним методом (EN 12393-2:1998, IDT).

11. ДСТУ EN 1528-1-2002 Продукти харчові жирові. Визначення пестицидів і поліхлорованих біфенілів (ПХБ) (ЕN 1528-1:1998).

12. ДСТУ ISO 10382:2004 Якість грунту. Визначення хлорорганічних пестицидів та поліхлорованих біфенілів. Газохроматографічний метод з детекцією захопленням електронів (ISO 10382:2002).

13. ДСТУ ISO 3890-1:2007 Молоко та молочні продукти. Визначення залишків хлорорганічних сполук (пестицидів) (ISO 3890-1:2000).

14. ДСТУ ISO 14182:2006 Корми для тварин. Визначення залишків фосфорорганічних пестицидів методом газової хроматографії (ISO 14182:1999, IDT).

15. ДСТУ ISO 14181:2003 Корми для тварин. Визначення залишків хлор-органічних пестицидів. Метод газової хроматографії (ISO 14181:2000, IDT).

16. ДСТУ ISO 6468-2002 Якість води. Визначання вмісту окремих хлорорганічних інсектицидів, поліхлорованих біфенілів і хлорбензолів. Метод газової хроматографії після екстрагування (рідина - рідина).

17. Мельничук С.Д. Методика виконання вимірювань масової частки залишкових пестицидів у грунті методом газорідинної хроматографії. МВВ № 081/120543-08.

18. С.Д. Мельничук, В.И. Лоханская, Ю.С. Баранов, В.И. Цвилиховский, О.В. Земцова, E.B. Жук. Определение множественных остатков пестицидов в почвах прискладских территорий. Журнал хроматографічного товариства, 2005. Т. V. N 3. С.4-10.

19. Кучма П.О. Комплексний контроль багатозалишкових кількостей пестицидів та ПАВ в грунтах різного призначення. Журнал хроматографічного товариства, 2016. Т. 16. N 1-4. C. 31-36. DOI: https://doi.org/10.15407/zht2016.59.031

20. Lokhanska V. Identification of Pollutants in Soils around the Obsolete Pesticides Stocks in Ukraine. Springer Science+Business Media B.V. 2008.

21. Anastassiades M. Fastand Easy Multiresidue Method Employing Acetonitrile Extraction. Partitioning and "Dispersive Solid-Phase Extraction" for the Determination of Pesticide Residues in Produce. Journal of AOAC International, 2003. N 86(2). P.412-431.

22. EN 15662-2008. Foods of plant origin - Determination of pesticide residues using GCMS and/or LC-MS/MS following acetonitrile extraction/partitioning and clean up by dispersive SPE - QuEChERS-method.

23. Quick Method for the Analysis of Residues of numerous Highly Polar Pesticides in Food Commodities involving Simultaneous Extraction with Methanol and Determination via LCMS/MS (QuPPe-AO-Method). CVUA Stuttgart, Schaflandstr., 3/2, 70736, Fellbach, Germany. EURL@cvuas.bwl.de

24. Analysis of Acidic Pesticides using QuEChER (EN15662) and acidified QuEChERS method. CVUA Stuttgart, Schaflandstr., 3/2, 70736, Fellbach, Germany.EURL@cvuas.bwl.de 
25. Sapozhnikova Y. Evaluation of low-pressure gas chromatography-tandem mass spectrometry method for the analysis of $>140$ pesticides in fish. J. Agric. Food Chem., 2014. N 62. P. 3684-3689. DOI: https://doi.org/10.1021/jf404389e

26. Лимиан Жао (Limian Zhao) и Дерик Лукас (Derick Lucas). Многокомпонентный анализ остатков пестицидов в авокадо с помощью Agilent Bond Elut EMR-Lipid методом ГХMC-MC. Рекомендации $\kappa$ применению, материаль Agilent Technologies, Inc. URL: https://www.agilent.com/cs/library/applications

27. Лимиан Жао (Limian Zhao) и Дерик Лукас (Derick Lucas) Многокомпонентный анализ ветеринарных препаратов в бычьей печени методом ЖХ-МС-МС. Рекомендации к применению, материаль Agilent Technologies, Inc. URL: https://www.agilent.com/cs/library/applications/

28. С.Д. Мельничук, В.Й. Лоханська, Ю.С. Баранов, А.О. Білоус. Проблеми визначення залишків пестицидів у зерновій продукції та шляхи їх вирішення. Журнал хроматографічного товариства, 2009. T. IX. N 1, 2. C.13-18.

\section{REFERENCES}

1. Klisenko M.A., Aleksandrova L.A., Demchenko V.F., Makarchuk T.L. Analytical chemistry of pesticides residues: Teaching manual. Kyiv: ECOHINTOKS, 1999, 238 p.

2. Pysmennaya M.V., Klisenko M.A. Guidelines for determining in one sample organophosphate and organochlorine pesticides used on tomatoes by chromatographic methods ( $\mathrm{N}$ 4994-89 by 08.06.89). Methods for the determination of trace amounts of pesticide microquantities in food, feed and the environment. Handbook. Moskow: Agropromizdat, 1992. V.2. P. 74-80.

3. Pysmennaya M.V., Girenco D.B., Klisenko M.A. Guidelines by determination of synthetic pyrethroids, organophosphate pesticides, sevine and benomyl with the joint presence in fruit and vegetable crops (N 4994-89 by 08.06.89). Methods for the determination of trace amounts of pesticide microquantities in food, feed and the environment. Handbook. Moskow: Agropromizdat, 1992. V.2. P. 80-83.

4. Kofman I.Sh., Klisenko M.A., Kofanov V.I. Guidelines for the systematic gaschromatographic determination of microquantities of herbicides of various chemical nature with the joint presence in samples of water, soil and plants ( $\mathrm{N} \mathrm{3022-84}$ by 27.04.84). Methods for the determination of trace amounts of pesticide microquantities in food, feed and the environment. Handbook. Moskow: Agropromizdat, 1992. V.2. P. 83-89.

5. Aleksandrova L.A., Demchenko V.F., Klisenko M.A. Guidelines for the systematic analysis of biological media on the content of pesticides of various chemical nature (N 4362-87 by 08.06.87). Methods for the determination of trace amounts of pesticide microquantities in food, feed and the environment. Handbook. Moskow: Agropromizdat, 1992. V.2. P. 89-94.

6. Girenco D.B., Klisenko M.A., Pysmennaya M.V., Chmil V.D. Unified method for the determination of pesticide residues with the joint presence in the diet (N 4380-87 by 08.06.87). Methods for the determination of trace amounts of pesticide microquantities in food, feed and the environment. Handbook. Moskow: Agropromizdat, 1992. V.2. P. 94-97.

7. Bublik L.I., Gavrilyuk L.L., Fedorenko N.V. Guidelines for the determination of a mixture of carbofuran with benomyl and TMTD (pesticide formulation COMBI) in sugar beet plants by thin layer chromatography (N 5021-89 by 08.06.89). Methods for the determination of trace amounts of pesticide microquantities in food, feed and the environment. Handbook. Moskow: Agropromizdat, 1992. V.2. P. 97-99.

8. Kavetsky V.I., Andrienko G.G., Lesovoy V.A. Guidelines for the determination of a mixture of metaphos, bayletone and tilt in wheat plants by thin layer chromatography (N 5036-89 by 08.06.89). Methods for the determination of trace amounts of pesticide microquantities in food, feed and the environment. Handbook. Moskow: Agropromizdat, 1992. V.2. P. 100-101. 
9. Baranov Yu.S., Khilik L.A. Klisenko M.A. Guidelines for the joint determination of prometryn, terbacil and trifluralin in one sample of soil, essential oil and essential oil raw peppermint by gas-liquid chromatography (N 2363-81 by 30.03.81). Methods for the determination of trace amounts of pesticide microquantities in food, feed and the environment. Handbook. Moskow: Agropromizdat, 1992. V.2. P. 101-105.

10. DSTU EN 12393-1,2,3:2003. No Fatty foods. Determination of pesticides residues by gas chromatography (EN 12393-1,2,3:1998, IDT).

11. DSTU EN 1528-1-2002. Fatty products. Determination of pesticides and polychlorinated biphenyls (PCBs) (EN 1528-1:1998).

12. DSTU ISO 10382:2004. Quality of soil. Determination of organochlorine pesticides and polychlorinated biphenyls. Gas chromatographic method with electron capture detector (ISO 10382:2002).

13. DSTU ISO 3890-1:2007. Milk and dairy products. Determination of residues of organochlorine pesticides) (ISO 3890-1:2000).

14. DSTU ISO 14182:2006. Animal feed. Determination of phosphorus-organic pesticide residues by gas chromatography (ISO 14182:1999, IDT).

15. DSTU ISO 14181:2003. Animal feed. Determination of residues of chlorine-organic pesticides. Gas chromatography method (ISO 14181:2000, IDT).

16. DSTU ISO 6468-2002 Water quality. Determination of residues of individual chloroorganic insecticides, polychlorinated biphenyls and chlorobenzenes. Method of gas chromatography after extraction (liquid-liquid).

17. Melnichuk S.D., Lokhanska V.I., Baranov Yu.S., Tsvilihovsky V.I., Zemtsova O.V., Pavlinchuk V.I. Method for measuring the mass fraction of residues of pesticides in the soil by gas-liquid chromatography. MVV N 081/120543-08.

18. Melnichuk S.D., Lokhanskaya V.I., Baranov Yu.S., Tsvilihovsky V.I., Zemtsova O.V., Zhuk T.V. Determination of multiresidues of pesticides in soils of the utilized areas. Zurnal Hromatograficnogo tovaristva, 2005. N 3. P. 4-10.

19. Kuchma P.O., Kushnir A.G., Zemtsova O.V., Baranov Yu.S. Complex control multiresidual amounts of pesticides and pahs in soils for various purposes. Zurnal Hromatograficnogo tovaristva. 2016, $\mathrm{N}$ 1-4. P. $31-36 . \quad$ DOI: https://doi.org/10.15407/zht2016.59.031

20. Lokhanska V., Melnychuk S., Baranov Yu. Identification of Pollutants in Soils around the Obsolete Pesticides Stocks in Ukraine. Springer Science + Business Media B.V. 2008.

21. Anastassiades M., Lehotay S. J., Stajnbaher D., Schenck F. J. Fast and Easy Multiresidue Method Employing Acetonitrile Extraction/Partitioning and "Dispersive Solid-Phase Extraction" for the Determination of Pesticide Residues in Produce. Journal of AOAC International, March 2003. N 86(2). P. 412-431.

22. EN 15662-2008. Foods of plant origin - Determination of pesticide residues using GCMS and/or LC-MS/MS following acetonitrile extraction/partitioning and cleanup by dispersive SPE - QuEChERS-method.

23. Quick Method for the Analysis of Residues of numerous Highly Polar Pesticides in Food Commodities involving Simultaneous Extraction with Methanol and Determination via LCM-MS (QuPPe-AO-Method). CVUA Stuttgart, Schaflandstr., 3/2, 70736, Fellbach, Germany. EURL@cvuas.bwl.de

24. Analysis of Acidic Pesticides using QuEChER (EN 15662) and acidified QuEChERS method. CVUA Stuttgart, Schaflandstr., 3/2, 70736, Fellbach, Germany.EURL@cvuas.bwl.de

25. Sapozhnikova Y. Evaluation of low-pressure gas chromatography-tandem mass spectrometry method for the analysis of $>140$ pesticides in fish. J. Agric. Food Chem. 2014. N 62. P. 3684-3689. DOI: https://doi.org/10.1021/jf404389e

26. Limian Zhao and Derick Lucas Multiresidues analysis of pesticides in avocados using Agilent Bond Elut EMR-Lipid by GC-MS-MS. Recommendations for use, materials. Agilent Technologies, Inc. https://www.agilent.com/cs/library/applications/ 
27. Limian Zhao and Derick Lucas Multiresidues analysis of veterinary drugs in the bovine liver by the method of LC-MS-MS. Recommendations for use, materials from Agilent Technologies, Inc. https://www.agilent.com/cs/library/applications/

28. Melnichuk S.D., Lohanska V. I., Baranov Yu.S., Belous A.O. Problems of determination of residues of pesticides in grain products and ways of their solution. Zurnal Hromatograficnogo tovaristva, 2009. N 1, 2. P. 13-18.

Українська лабораторія якості та безпеки продукції АПК НУБіП України, м. Київ ${ }^{1}$ ДУ «Інститут медиџини праці імені Ю.І. Кундієва Наџіональної академії медичних наук України», м. Київ

Надійшло до редакиії 26 листопада 2018 р. 